\title{
Repellent, Antifeedant and Insecticidal Effects of Neem oil on Microtheca punctigera
}

\author{
Adriana Yatie Mikami and Maurício Ursi Ventura* \\ Universidade Estadual de Londrina; Departamento de Agronomia; Campus Universitário; C.P. 6001; \\ mventura@uel.br; 86051-970; Londrina-PR - Brasil
}

\begin{abstract}
The effects of concentrations (0.00, 0.25, 0.50 and 1.00\%) of the neem tree (Azadirachta indica - Meliaceae) oil emulsion on the behavioral and biological parameters of $\mathrm{M}$. punctigera were investigated in the laboratory. Wild radish (Raphanus raphanistrum L.) host plant was used. Multiple and no-choice feeding preference assays were conducted which shown multiple effects. The males were repelled by the neem oil in multiple-choice assay. The adult (multiple-choice) and larvae (multiple and no-choice) feeding were deterred. The larvae mortality was higher in the neem oil treated than the control leaves. Further investigations are suggested to test neem oil in the management of the pest in the field.
\end{abstract}

Key words: Insecta, yellowmargined leaf beetles, botanical insecticide

\section{INTRODUCTION}

The leaf beetles of the genus Microtheca (Stål) (Coleoptera: Chrysomelidae) are closely related to host plants of the family Brassicaceae. These Neotropical insects are multivoltine oligophagous native to South America with records in Argentina, Brazil, Chile and Uruguai (Bowers, 2003). In Brazil, M. ochroloma (Stål) has been observed in the Rio de Janeiro and Rio Grande do Sul States (Silva et al., 1968; Racca Filho et al., 1994). Recently, high infestations of $M$. punctigera and M. semilaevis (Stål) were recorded on Chinese cabbage [Brassica pekinensis (Lour.) Rupr.] and mustard (B. juncea Cosson) (Menezes $\mathrm{Jr}$ and Mazuco, 1995; Farinha, 2003) in the Northern of Paraná State. These host plants are preferred by the larvae (Menezes Jr et al., 2005). M. ochroloma are exotic pest in the USA, with records in Alabama (Chamberlin and Tippins,
1948), Louisiana (Olivier and Chapin, 1983), Florida (Flowers et al., 1994, Bowers, 2003) and North Carolina (Staines, 1999). Some authors listed M. punctigera as synonym of M. ochroloma, but they were both recognized as distinct species through genitalic differences (Jolivet, 1950 apud Fasulo, 2005). The damage is done mostly by the larvae that are voracious and feed gregariously (Chamberlin and Tippins, 1948). Besides feeding, the larvae produce abundant excrements (Zorzenon et al., 1996).

Spraying synthetic insecticides can control the field populations of $M$. punctigera but alternative strategies have failed to manage $M$. ochroloma beetles, hence the pest is a serious limitation for the organic cultivations (Bowers, 2003). Botanicals insecticides are candidates to replace the conventional insecticides mostly by the organic farmers. The neem tree (Azadirachta indica. Juss) (Meliaceae) has got great interest in

\footnotetext{
* Author for correspondence
} 
this regard. Neem was considered safe to the humans and animals due to relative low toxicity (Boeke et al., 2004). Several reports have described the antifeedant, repellent and growthmodifying neem properties on the insects, which was essentially due to the terpenoid azadirachtin from the neem fruits (Carvalho and Trevisan, 1990; Schmutterer, 1990).

This study deals with the effects of applying the neem oil on the leaves of the wild radish (Raphanus raphanistrum L.) on the biological and behavioral parameters of M. punctigera beetles.

\section{MATERIAL AND METHODS}

The insects were collected in a Chinese cabbage field in Londrina in the state of Paraná, Brazil $\left(23^{\circ} 19^{\prime} \mathrm{S}, 51^{\circ} 12^{\prime} \mathrm{W}\right)$. The beetles were kept in the acrylic box (gerbox) and the insects were provided with Chinese cabbage leaves. The experiments were carried out in an environmental chamber maintained at $25 \pm 2{ }^{\circ} \mathrm{C}, 65 \pm 10 \% \mathrm{RH}$ and a photoperiod of L12: D12 h. Wild radish leaf discs $(2.0 \mathrm{~cm}$ diameter) were used in all the assays. The discs were disposed on the humid paper filter in the Petri dishes $(9.0 \mathrm{~cm}$ diameter). The neem oil emulsion (Dalneem ${ }^{\circledR}$, Blumenau, Santa Catarina, Brazil) formulated from $8.5 \%$ extract of the neem fruits was used. The leaf discs were dipped (10 seconds) in the aqueous neem solutions at 0.00 , $0.25,0.50$ and $1.00 \%$. The feeding was measured $24 \mathrm{~h}$ later. The images of the leaves were digitized and fed area was established using Siarcs software (Jorge, 1997).

\section{Multiple-choice assays}

Third instar larvae and adults were tested. The discs of the host plant were regularly distributed in the periphery of the Petri dishes (one disc per treatment). The adults were starved for $24 \mathrm{~h}$ prior to the test. One insect was placed in the center of the Petri dishes. In the test with the adults, the insects were observed for $1 \mathrm{~h}$ and the first leaf disc visited was recorded in the repellency effect. Due to the strong repellency of the treated leaves, data of the concentrations were grouped and compared to the control treatment. After $24 \mathrm{~h}$, the insects were removed and feeding area was measured.

\section{No-choice assay}

In this assay only the larvae (third instar) were investigated due to lesser dispersion and greater damage than the adults. The insects were tested in the same conditions and the procedures of the previous test, including the treatments. However, only one treated leaf disc was offered to each insect. The leaf discs were replaced daily. The feeding and accumulated mortality were recorded until the insect reached pupae stage. The mortality was recorded four, six and at the end of the experiment.

\section{Experimental Design and Statistical Analysis}

The multiple-choice assays were replicated 30 times for variable most visited. The feeding assessments were replicated 29, 30, 26 by male, female and larvae, respectively. The no-choice tests were replicated 30 times. For most visited first variable, the Fisher's exact test was carried out (Curi, 1997). The feeding in the multiplechoice assays was submitted to the Friedman's test and feeding in the no-choice assay was compared by the Kruskal-Wallis's test (Conover, 1980). For the accumulated mortality variable, ANOVA was performed and Tukey's range test (HSD) was used to compare individual's means $(\mathrm{p}<5)$ (SAS Institute, 1989).

\section{RESULTS AND DISCUSSION}

\section{Multiple-choice assays}

The males of $M$. punctigera visited mostly the leaf discs of the untreated wild radish than the neem oil treated ones (Table 1). The remaining insects did not visit any host during the bioassay.

The insect placement and feeding on the neem oil treated leaves were deterred prior to the contact.

The repellency is one of the principal features in the neem-derived products. Canola plants treated with the neem-derived commercial formulations were significantly less damaged by Phyllotreta cruciferae (Goeze) (Coleoptera: Chrysomelidae) than the untreated plants and the repellency was recorded in different periods after the treatment (Palaniswamy and Wise, 1994). Cryptolestes ferrugineus (Stephens) (Coleoptera: Laemophloeidae), Sitophilus oryzae (L.) (Coleoptera: Curculionidae), and Tribolium castaneum (Herbst) (Coleoptera: Teneobrinidae) were repelled by the neem extracts and azadirachtin (Xie et al., 1995). Application of a commercial formulation of Neem (RD-Repelin) successfully deterred pea aphids, Acyrthosiphon pisum (Harris) (Homoptera: Aphididae) attempting 
to land, probe or oviposit (Hunter and Ullman, 1992).

Table 1 - Preference (percentage of insects) of $M$. punctigera males or females in multiple-choice tests by untreated leaves of wild radish or leaves treated with neem oil, one hour after onset of the experiment in the laboratory $\left(25^{\circ} \mathrm{C}\right.$ $\pm 2^{\circ} \mathrm{C}$ and photoperiod of L12: D12 h).

\begin{tabular}{|c|c|c|}
\hline \multirow{2}{*}{ Sex } & \multicolumn{2}{|c|}{ Treatments * } \\
\hline & Control & Neem oil \\
\hline Females & $33.3 \mathrm{a}$ & $26.7 \mathrm{a}$ \\
\hline Males & $66.7 \mathrm{a}$ & $6.6 \mathrm{~b}$ \\
\hline
\end{tabular}

The females were not repelled by the neem oil since similar percentage of the females visited the treated and untreated leaf discs (Table 1). The responses to neem-derived products according to gender have been previously reported. The females of Chrotogonus homalodemus (Blanch) (Orthoptera: Acrididae) showed greater reluctant feeding behavior than the males to neem extracts (Grahn, 1993).

The females of Spodoptera litura (F.) (Lepidoptera: Noctuidae) feeding on the artificial diets showed a stronger response to azadirachtin, with large differences between the controls and treated diet compared to the males (Huang et al., 2004). The females of the parasitoids Trichogramma chilonis Ishii (Hymenoptera: Trichogrammatidae) were affected by the neem seed oil but the males were unaffected in the contact toxicity tests (Raguraman and Singh, 1999).

The feeding of the adults (males and females) and larvae of M. punctigera was significantly reduced in the neem oil treated leaves of the wild radish in the multiple-choice assay (Table 2). Similar feeding reduction was observed in the three concentrations applied $(0.25,0.50$ and $1.00 \%)$. The antifeedant and deterrent effects of the neem derived were also related for the Chrysomelidae beetles Acalymma vittatum (F.), Diabrotica undecimpunctata Howard Barber (Reed et al., 1982) and Leptinotarsa decemlineata Say (Zabel et al., 2002). Besides neem, other Meliaceae tree, Melia azedarach (L.) products produced antifeedant effect on Diabrotica speciosa (Genn.) (Coleoptera: Chrysomelidae) (Ventura and Ito, 2000).

Table 2 - Leaf consumption [feeding $\left(\mathrm{mm}^{2}\right)$ ] of males, females and third instar larvae of $M$. punctigera on leaf discs of untreated wild radish or treated with different concentrations of neem oil in multiple-choice assay, $24 \mathrm{~h}$ after assay onset, in the laboratory $\left(25^{\circ} \mathrm{C} \pm 2^{\circ} \mathrm{C}\right.$ and photoperiod of L12: D12 h).

\begin{tabular}{cccc}
\hline Treatments & \multicolumn{3}{c}{ Leaf consumption area $*$} \\
\cline { 2 - 4 }$(\boldsymbol{\%})$ & Males & Females & Larvae \\
\hline Neem oil $(1.00)$ & $0.5(0.3) \mathrm{b}$ & $2.2(1.0) \mathrm{b}$ & $0.7(0.5) \mathrm{b}$ \\
Neem oil $(0.50)$ & $3.3(1.8) \mathrm{b}$ & $2.6(1.0) \mathrm{b}$ & $1.0(0.4) \mathrm{b}$ \\
Neem oil $(0.25)$ & $0.9(0.3) \mathrm{b}$ & $5.0(1.8) \mathrm{b}$ & $2.8(1.2) \mathrm{b}$ \\
Control $(0.00)$ & $17.1(1.8) \mathrm{a}$ & $21.0(3.5) \mathrm{a}$ & $20.0(2.7) \mathrm{a}$ \\
\hline
\end{tabular}

* Means ( \pm S.E.) [Percentage of rank sums in relation to maximum possible score $(100 \%)]$. Means in the same column with different letter are significantly different by Friedman's test $(\mathrm{p}<0.05), \mathrm{n}=29,30$ and 26, males, female and larvae receptivity.

\section{No-choice assays}

In general, the neem oil treated leaves were less consumed than the untreated ones (Table 3). The feeding reduction was observed mostly on the higher concentrations $(0.50$ and $1.00 \%)$. The magnitude of the feeding reduction of the neem oil was apparently lesser in no-choice than in the multiple-choice assay due to alternative foods (Tables 1 and 2).
The larval mortality was higher in the neem oil treated leaf disks $(0.25,0.50$ and $1.00 \%)$ than control leaf disks in the first assessment (four days after the experiment onset) (Table 4). Higher mortality was also observed in higher dosage $(1.00 \%)$ than in the lower $(0.25 \%)$. Intermediate mortality rates were correspondent to the intermediate dosage $(0.50 \%)$. In the second period of the assessment (4 to 6 days), 100\% mortality was found for the treatment with the higher dosage 
$(1.00 \%)$ of the neem oil treated leaf disks. Similar values of the accumulated mortality was found
(93\%) for 0.25 and $0.50 \%$ treated neem oil leaf disks in the last assessment.

Table 3 - Feeding $\left(\mathrm{mm}^{2}\right)$ of $M$. punctigera larvae on leaf discs of untreated wild radish or treated with different concentrations of neem oil, 24, 48 and $72 \mathrm{~h}$ after the onset of experiment, in no-choice assays, $24 \mathrm{~h}$ after assay onset, in the laboratory $\left(25^{\circ} \mathrm{C} \pm 2^{\circ} \mathrm{C}\right.$ and photoperiod of $\left.\mathrm{L} 12: \mathrm{D} 12 \mathrm{~h}\right)$.

\begin{tabular}{lccc}
\hline Treatments (\%) & $\mathbf{2 4} \mathbf{~ h}$ & $\mathbf{4 8} \mathbf{~ h}$ & $\mathbf{7 2} \mathbf{~ h}$ \\
\hline Neem oil $(1.00)$ & $6.9(0.9)[36.6] \mathrm{b}$ & $3.6(0.7)[18.8] \mathrm{c}$ & $1.4(0.5)[19.8] \mathrm{b}$ \\
Neem oil $(0.50)$ & $9.0(1.0)[50.4] \mathrm{b}$ & $3.1(0.6)[17.2] \mathrm{c}$ & $1.7(0.9)[18.5] \mathrm{b}$ \\
Neem oil $(0.25)$ & $13.3(1.2)[71.6] \mathrm{a}$ & $11.5(1.2)[36.2] \mathrm{b}$ & $19.6(5.2)[29.5] \mathrm{b}$ \\
Control $(0.00)$ & $17.2(1.6)[83.3] \mathrm{a}$ & $18.9(2.3)[49.9] \mathrm{a}$ & $42.1(4.1)[48.9] \mathrm{a}$ \\
\hline * Means $( \pm$ S.E.) [Means rank] in the same column with different letter are significantly different by Kruskal-Wallis's test $(\mathrm{p}<0.05), \mathrm{n}=30$.
\end{tabular}

Table 4 - Accumulated mortality percentage of $M$. punctigera larvae fed on wild radish leaf discs or wild radish treated with concentrations of neem oil (until 4, 4 to 6 , and after 6 days after treatment) in no-choice assays in the laboratory $\left(25^{\circ} \mathrm{C} \pm 2{ }^{\circ} \mathrm{C}\right.$ and photoperiod of L12: D12 h).

\begin{tabular}{|c|c|c|c|c|c|c|}
\hline Treatments (\%) & & & & $y(c$ & & \\
\hline & & & & & & \\
\hline Neem oil (1.00) & 70 & $\mathrm{~A}^{*}$ & 100 & $\mathrm{~A}$ & 100 & A \\
\hline Neem oil $(0.50)$ & 40 & $\mathrm{AB}$ & 86 & A & 93 & A \\
\hline Neem oil $(0.25)$ & 30 & B & 63 & A & 93 & $\mathrm{~A}$ \\
\hline Control $(0.00)$ & 0 & $\mathrm{C}$ & 0 & $\mathrm{~B}$ & 3 & B \\
\hline
\end{tabular}

* Proportions in the same column with different letter are significantly different by Tukey's test $(\mathrm{p}<0.05)$.

While in the lower dosage $(0.25 \%)$, the insect mortality was regularly distributed in the three periods of the observation, mortality in the higher dosage treatment $(1.00 \%)$ concentrated in the first (mostly) and second periods (Table 4). Hence, progressive dosages of the neem oil resulted on $M$. punctigera larvae earlier death.

The malformation and mortality is referred as the dose-dependent in the insect feeding on the neem treated hosts due to various developmental, postembryonic, reproductive and growth inhibitory effects (Ascher, 1993). Mordue and Blackwell (1993) referred to neem effects as dose and time dependent, preventing both the ecdysis and apolysis, and causing death before or during the molting, possibly inducing "permanent" larvae.

The leaf beetles (Chrysomelidae) have been recorded as susceptible to the Meliaceae plant derivates. The larvae of the elm beetle Xanthogalleruca luteola (Muller) forced to feed on $M$. azedarach extracts treated leaves died without molting and mortality also increased dramatically in the adults fed on the treated leaves (Valladares et al., 1997). The mortality of $P$. cruciferae was related when the plants of the canola were treated with the neem commercial formulations (Palaniswamy and Wise, 1994). The larvae of $L$. decemlineata showed a high mortality when treated directly with the neem oil of the seed kernels or fed on the oil treated leaves (Kaethner, 1992).

The neem oil exhibited the previously reported repellent (males), antifeedant and insecticidal effects to M. punctigera. The field assessment may be achieved to determine if neem oil is a suitable tool to manage the pest. Otherwise, M. punctigera is naturally controlled by Beauveria bassiana and Strongygaster brasiliensis (Towsend) (Diptera: Tachinidae) in the field (Farinha, 2003). The tests evaluating the compatibility between the neem and these biological control agents are also desirable.

\section{ACKNOWLEDGEMENTS}

We thank CNPq (Conselho Nacional de Desenvolvimento Científico e Tecnológico) for the MSc research scholarship to the first author of this work; Dr. Inês Cristina de Batista Fonseca (Department of Agronomy, Universidade Estadual de Londrina, Londrina, PR) for her assistance with the statistics; David Tramontina for the plant cultivation and insect rearing assistance. 


\section{RESUMO}

Besouros Microtheca punctigera (Achard) são pragas sérias de plantas hospedeiras da família Brassicaceae. Efeitos das concentrações $(0,00$; 0,25; 0,50; e 1,00\%) do óleo emulsionável de nim (Azadirachta indica - Meliaceae) sobre parâmetros de comportamento e biologia de $M$. punctigera foram investigados em laboratório. Nabiça (Raphanus raphanistrum L.) foi a planta hospedeira utilizada. Ensaios de preferência alimentar com múltipla e sem chance de escolha foram conduzidos. Múltiplos efeitos do óleo de nim foram observados. Machos foram repelidos pelo óleo de nim em teste de múltipla escolha. Adultos (múltipla escolha) e larvas (múltipla e sem chance de escolha) sofreram deterrência. A mortalidade de larvas foi mais elevada nos tratamentos com óleo de nim que no tratamento controle. Futuras investigações são sugeridas para testar o óleo de nim no manejo de pragas no campo.

\section{REFERENCES}

Ascher, K. R. S. (1993), Nonconventional insecticidal effects of pesticides available from the Neem tree, Azadirachta indica. Arch. Ins. Biochem. Physiol., 22, 433-449.

Boeke, S. J., Boersma, M. G., Alink, G. M., Loon, J. J. A. van, Huis, A. van, Dicke, M. and Rietjens, M. C. M. (2004), Safety evaluation of neem (Azadirachta indica) derived pesticides. J. Ethnopharmacol., 94, 25-41.

Bowers, K. (2003), Effects of within-field location of host plants and intercropping on the distribution of Microtheca Ochroloma (Stål) in Mizuna. M.S. Thesis. University of Florida, Gainesville, Florida, United States of America.

Carvalho, S. M. and Trevisan, D. (1990), Santa-bárbara contra a vaquinha. Ciência Hoje, 11, 65-67.

Chamberlin, F. S. and Tippins, H. H. (1948), Microtheca ochroloma, an introduced pest of crucifers, found in Alabama. J. Econ. Entomol., 41, 979-980.

Conover, W. J. (1980), Practical nonparametric statistics, 2nd ed. Wiley, New York.

Curi, P. R. (1997), Metodologia e análise da pesquisa em Ciências Biológicas, Botucatu.

Farinha, L. F. C. (2003), Ciclo de vida de Microtheca punctigera Achard, 1917 e Microtheca semilaevis Stal, 1860 (Coleoptera: Chrysomelidae) em duas dietas e preferência alimentar em condições de campo e laboratório. Dissertação (Mestrado em Agronomia)
- Universidade Estadual de Londrina, Londrina, Paraná, Brasil.

Fasulo, T. R. (2005), Yellowmargined leaf beetle, Microtheca ochroloma Stål. UF/IFAS Featured Creatures.EENY-348.

http://creatures.ifas.ufl.edu/veg/leaf/yellowmargined_ leaf_beetle.htm.

Flowers, R. W., Furth, D. G. and Thomas, M. C. (1994), Notes on the distribution and biology of some Florida leaf beetles (Coleoptera: Chrysomelidae). Coleop. Bull., 48, 79-89.

Grahn, B. (1993), Different feeding-behavior of the 2 sexes of Chrotogonus-Homalodemus (Blanch) (Orthoptera: Acrididae) and repellency of an aqueous neem seed kernel extract (NSKE). Anz. Schad. Pflanzen. Umwelt., 66, 46-48.

Huang, Z., Shi, P., Dai, J. and Du, J. (2004), Protein metabolism in Spodoptera litura (F.) is influenced by the botanical insecticide azadirachtin. Pest. Biochem. Physiol., 80, 85-93.

Hunter, W. B. and Ullman, D. E. (1992), Effects of the Neem product, Rd-Repelin, on settling behavior and transmission of Zucchini Yellow Mosaic Virus by the Pea Aphid, Acyrthosiphon pisium (Harris) (Homoptera: Aphididae). Ann. Appl. Biol., 120, 9-15.

Jorge, L. A. C. (1997), Recomendações práticas para aquisição de imagens digitais analisadas através do Siarcs. Embrapa - Instrumentação Agropecuária, São Carlos. CD-ROM.

Kaethner, M. (1992), Fitness reduction and mortality effects of neem-based pesticides on the Colorado Potato Beetle Leptinotarsa decemlineata Say (Col, Chrysomelidae). J. Appl. Entomol.-Zeitsch. Angew. Entomol., 113, 456-465.

Menezes Jr, A. O. and Mazuco, C. (1995), O ciclo de vida de Microtheca punctigera Achard, 1917 (Coleoptera: Chrysomelidae) em couve-chinesa (Brassica pekinensis). In: Congresso Brasileiro de Entomologia, 15, Caxambu, MG; Resumos...; Lavras: SEB/ESAL, 1995. 406 p.

Menezes Jr, A. O., Mikami, A. Y., Ide, A. K. and Ventura, M. U. (2005), Feeding preferences of Microtheca punctigera (Achard) (Coleoptera: Chrysomelidae) for some Brassicaceae plants in multiple-choice assays. Scientia Agric., 62, 72-75.

Mordue, A. J. and Blackwell, A. (1993), Azadirachtin: an update. J. Ins. Physiol., 39, 903-924.

Oliver, A. D. and Chapin, J. B. (1983), Biology and distribution of the yellowmargined leaf beetle, Microtheca ochroloma Stal, with notes on M. Picea (Guérin) (Coleoptera: Chrysomelidae) in Louisiana. J. Georgia Entomol. Society, 18, 229-234.

Palaniswamy, P. and Wise, I. (1994), Effects of neembased products on the number and feeding-activity of a crucifer flea beetle, Phyllotreta cruciferae (Goeze) (Coleoptera, Chrysomelidae), on canola. J. Agric. Entomol., 11, 49-60. 
Racca Filho, F., Rodrigues Filho, I. L., Santos, C. A. C. and Rodrigues C. N. (1994), Microtheca ochroloma (Coleoptera: Chrysomelidae): aspectos taxonômicos e biológicos. Rev. Univ. Rural, 16, 29-35.

Raguraman, S. and Singh, R. P. (1999), Biological effects of neem (Azadirachta indica) seed oil on an egg parasitoid, Trichogramma chilonis. J. Econ. Entomol., 92, 1274-1280.

Reed, D. K., Warthen Jr, J. D., Uebel, E. C. and Reed, G. L. (1982), Effects of two triperpenoids from neem on feeding by cucumber beetles (Coleoptera: Chrysomelidae). J. Econ. Entomol., 75, 1109-1113.

SAS Institute (1989), Sas/Stat. User's Guide, Version 6, 4th. Ed. Sas Institute, Cary, Nc.

Silva, A. G. D'A., Gonçalves, C. R., Galvão, D. M., Gonçalves, A. J. L., Gomes, J., Silva, M. N. and Simoni, L. (1968), Quarto catálogo dos insetos que vivem nas plantas do Brasil, seus parasitas e predadores, Rio de Janeiro: Ministério da Agricultura, $622 \mathrm{pp}$.

Staines, C. L. (1999), Chrysomelidae (Coleoptera) new to North Carolina. Coleop.-Bull., 53, 27-29.

Schmutterer, H. (1990) Properties and potential of natural pesticides from the neem tree, Azadiracta indica. Annu. Rev. Entomol., 35, 271-297.
Valladares, G., Defago, M.T., Palacios, $\mathrm{S}$ and Carpinella, M.C. (1997), Laboratory evaluation of Melia azedarach (Meliaceae) extracts against the elm leaf beetle (Coleoptera: Chrysomelidae). J. Econ. Entomol., 90, 747-750.

Ventura, M. U. and Ito, M. (2000), Antifeedant activity of Melia azedarach (L.) extracts to Diabrotica speciosa (Genn.) (Coleoptera: Chrysomelidae) beetles. Braz. Arch. Biol. Technol., 2, 15-219.

Xie, Y. S., Fields, P. G. and Isman, M. B. (1995), Repellency and toxicity of azadirachtin and neem concentrates to 3 stored-product beetles. J. Econ. Entomol., 88, 1024-1031.

Zabel, A., Manojhovic, B., Rajkovic, S., Strankovic, S. and Kostic, M. (2002), Effect of neem extract on Lymantria dispar L. (Lepidoptera: Lymantriidae) and Leptinotarsa decemlineata Say (Coleoptera: Chrysomelidae). J. Pest Science, 75, 19-25.

Zorzenon, F. J., Imenes, S. D. L., Bergmann, E. C. and Boock, M. V. (1996), Biologia de Microtheca punctigera (Achard) (Coleoptera: Chrysomelidae). Arq. Inst. Biol., 63, 7-9. 